\title{
Cervical spine involvement in patients with chronic arthritis undergoing orthopaedic surgery
}

\author{
E. ORNILLA, B. M. ANSELL, AND A. J. SWANNELL \\ MRC Rheumatism Research Unit, Canadian Red Cross Memorial Hospital, Taplow, Maidenhead, Heatherwood \\ Hospital, Ascot, and Wexham Park Hospital, Slough
}

Subluxation of the cervical spine due to rheumatoid arthritis is well recognized as a radiological entity (Sharp and Purser, 1961). It can cause compression of the spinal cord, leading to neurological complications or death (Davis and Markley, 1951; Martel and Abell, 1963). Manipulation or slight trauma under anaesthesia may be the triggering factor (Hopkins, 1967; Whaley and Carson Dick, 1968: Isdale, Ridings, and Tapsell, 1964).

The present study was suggested when a patient who was due to come in for arthroplasty of the knee was sent up as an emergency because of neurological symptoms in the right arm, secondary to atlantoaxial subluxation.

Radiological examination of the cervical spine was performed in 100 patients before orthopaedic procedures of various types, as part of the management of their arthritis; this included 23 patients with juvenile chronic polyarthritis.

\section{Material and methods}

The first 100 consecutive patients in 1971 were studied; 77 had definite or classical rheumatoid arthritis according to the American Rheumatism Association criteria, and 23 had juvenile chronic polyarthritis defined according to Ansell and Bywaters (1959) (Table I). Of the juvenile patients, sixteen were thought to have Still's disease and seven were considered to have rheumatoid arthritis of adult type commencing below 16 years of age, according to the pattern of joint involvement, presence of nodules, early

Table I Patients studied

\begin{tabular}{|c|c|c|c|}
\hline Diagnosis & $\begin{array}{l}\text { Rheumatoid } \\
\text { arthritis }\end{array}$ & $\begin{array}{l}\text { Still's } \\
\text { disease }\end{array}$ & $\begin{array}{l}\text { Juvenile } \\
\text { rheumatoid } \\
\text { arthritis }\end{array}$ \\
\hline No. of patients & 77 & 16 & 7 \\
\hline $\begin{array}{l}\text { Mean age (yrs) } \\
\text { Mean duration (yrs) }\end{array}$ & $\begin{array}{l}52 \cdot 0 \\
10\end{array}$ & $\begin{array}{l}21 \cdot 5 \\
14 \cdot 1\end{array}$ & $\begin{array}{l}23 \cdot 9 \\
12 \cdot 6\end{array}$ \\
\hline
\end{tabular}

development of erosions in hands and feet, and positive serology (Ansell, 1969). The age at the time of surgery in the 77 adults suffering from rheumatoid arthritis ranged from 22 to 79 years (mean 52) and in the 23 with juvenile chronic polyarthritis from 11 to 59 years (mean 22). The duration of disease ranged from 1 to 40 years in the cases of adult rheumatoid arthritis and from 8 months to 54 years in the second group.

The following orthopaedic procedures were carried out :

32 Arthroplasty of hip or knee

37 Synovectomy of large or small joints

10 Ulnar styloidectomy

6 Fowler's operation

4 Extensor tendon repair

3 Carpal tunnel decompression

3 Epiphyseal stapling

3 Knee exploration, including biopsy

1 Wrist manipulation

1 Multiple toe tenotomies

Lateral radiographs of the cervical spine, taken in full flexion and full extension, with the tube at 5 feet distance and centered on the 2 nd vertebra, were done in each patient. The $x$-rays were read by at least two observers. The depth of the anterior atlanto-axial joint was taken as the distance between the middle of the posterior surface of the anterior arch of the atlas and the anterior surface of the odontoid process. The maximum 'normal' distance for the patient under 45 years was taken as $4 \mathrm{~mm}$. and over that age as $3 \mathrm{~mm}$. (Sharp and Purser, 1961). Subluxation in the lower cervical spine was recorded when the loss of alignment between the anterior bodies of two vertebrae was greater than $2 \mathrm{~mm}$. The presence of erosions and sclerosis in the atlanto-axial joint and the fusion of the apophyseal joints was also recorded.

\section{Results}

The significant radiological abnormalities due to rheumatoid arthritis are shown in Table II. These consisted of atlanto-axial subluxation (14), lower subluxation (11) and apophyseal joint fusion (11). The atlanto-axial subluxation was confined to those suffering from adult or juvenile rheumatoid arthritis; 
Table II Incidence of radiological change

\begin{tabular}{|c|c|c|c|}
\hline Diagnosis & $\begin{array}{l}\text { Rheumatoid } \\
\text { arthritis }\end{array}$ & $\begin{array}{l}\text { Still's } \\
\text { disease }\end{array}$ & $\begin{array}{l}\text { Juvenile } \\
\text { rheumatoid } \\
\text { arthritis }\end{array}$ \\
\hline No. of patients & 77 & 16 & 7 \\
\hline $\begin{array}{l}\text { Atlanto-axial } \\
\text { subluxation }\end{array}$ & 10 & 0 & 4 \\
\hline $\begin{array}{l}\text { Lower subluxation } \\
\text { Apophyseal joint } \\
\text { fusion }\end{array}$ & $\begin{array}{l}8 \\
0\end{array}$ & $\begin{array}{l}1 \\
8\end{array}$ & $\begin{array}{l}2 \\
3\end{array}$ \\
\hline
\end{tabular}

subluxation lower in the cervical spine was also most usual in these groups, but was seen in one patient with Still's disease. Apophyseal joint fusion was common in both groups of juveniles (case histories 1 and 2). When the duration of the disease was related to cervical spine involvement, in adult rheumatoid arthritis, only two patients had evidence of subluxation at the atlanto-axial site or lower, with less than 5 years' duration of disease. The same is also true in juvenile rheumatoid arthritis. In Still's disease the predominant lesion was in apophyseal joints (Table III).

The operation performed on those with abnormal cervical spines are shown in Table IV.

Cervical spine abnormalities were thus related to the duration of disease rather than to any particular operative procedure.
Table IV Treatment

\begin{tabular}{|c|c|c|c|}
\hline Diagnosis & Synovectomy & Arthroplasty & Other \\
\hline $\begin{array}{l}\text { Atlanto-axial } \\
\text { subluxation }\end{array}$ & 5 & 6 & 3 \\
\hline $\begin{array}{l}\text { Low cervical } \\
\text { subluxation }\end{array}$ & 3 & 5 & 3 \\
\hline $\begin{array}{l}\text { Apophyseal } \\
\text { joint fusion }\end{array}$ & 2 & 5 & 4 \\
\hline
\end{tabular}

Among those with atlanto-axial subluxation (Fig. 1 , overleaf), only one had any severe sequelae. She had pain and a 'clonking' feeling in the neck after a Shiers arthroplasty of the knee; she has subsequently had a cervical fusion. One other patient previously known to have atlanto-axial subluxation and taken to theatre in her collar, did have some recurrence of neck pain postoperatively, but this has now settled. The main problem has been that of intubation due to lack of neck movement and difficulty in opening the mouth, this has occurred only in the patients with an early age at onset (Case 2).

\section{Case 1}

At the age of 12 years over a 2-month period, this patient developed symmetrical small joint polyarthritis of the upper and lower limbs. The erythrocyte sedimentation rate was $119 \mathrm{~mm}$./first hr. DAT 1:128. Latex ++. By 3 months the radiographs showed early erosions of the

Table III Duration of disease related to cervical spine involvement

\begin{tabular}{|c|c|c|c|c|c|c|c|}
\hline \multirow[t]{2}{*}{ Diagnosis } & \multirow{2}{*}{$\begin{array}{l}\text { Cervical } \\
\text { spine } \\
\text { involvement }\end{array}$} & \multicolumn{6}{|c|}{ Duration (yrs) } \\
\hline & & $0-5$ & $6-10$ & $11-20$ & $21-30$ & $31-40$ & Over 40 \\
\hline \multirow{3}{*}{$\begin{array}{l}\text { Rheumatoid } \\
\text { arthritis } \\
\text { (78) }\end{array}$} & Atlanto-axial & 1 & 6 & 3 & 1 & 0 & 0 \\
\hline & $\begin{array}{l}\text { subluxation } \\
\text { Lower } \\
\text { subluxation }\end{array}$ & 1 & 3 & 3 & 1 & 0 & 0 \\
\hline & Total cases & 21 & 27 & 22 & 7 & 1 & 0 \\
\hline \multirow{4}{*}{$\begin{array}{l}\text { Juvenile } \\
\text { rheumatoid } \\
\text { arthritis } \\
\text { (7) }\end{array}$} & $\begin{array}{r}\text { Atlanto-axial } \\
\text { subluxation }\end{array}$ & 0 & & 3 & & & \\
\hline & $\begin{array}{l}\text { Lower } \\
\text { subluxation }\end{array}$ & 1 & & 1 & & & \\
\hline & $\begin{array}{l}\text { Apophyseal } \\
\text { fusion }\end{array}$ & 1 & & 2 & & & \\
\hline & Total cases & 1 & & 6 & & & \\
\hline \multirow{4}{*}{$\begin{array}{l}\text { Still's } \\
\text { disease } \\
\text { (16) }\end{array}$} & Atlanto-axial & 0 & & 0 & 0 & & 0 \\
\hline & Lower & 0 & & 1 & 0 & & 0 \\
\hline & $\begin{array}{l}\text { Apophyseal } \\
\text { fusion }\end{array}$ & 2 & & 4 & 1 & & 1 \\
\hline & Total cases & 6 & & 6 & 3 & 0 & 1 \\
\hline
\end{tabular}



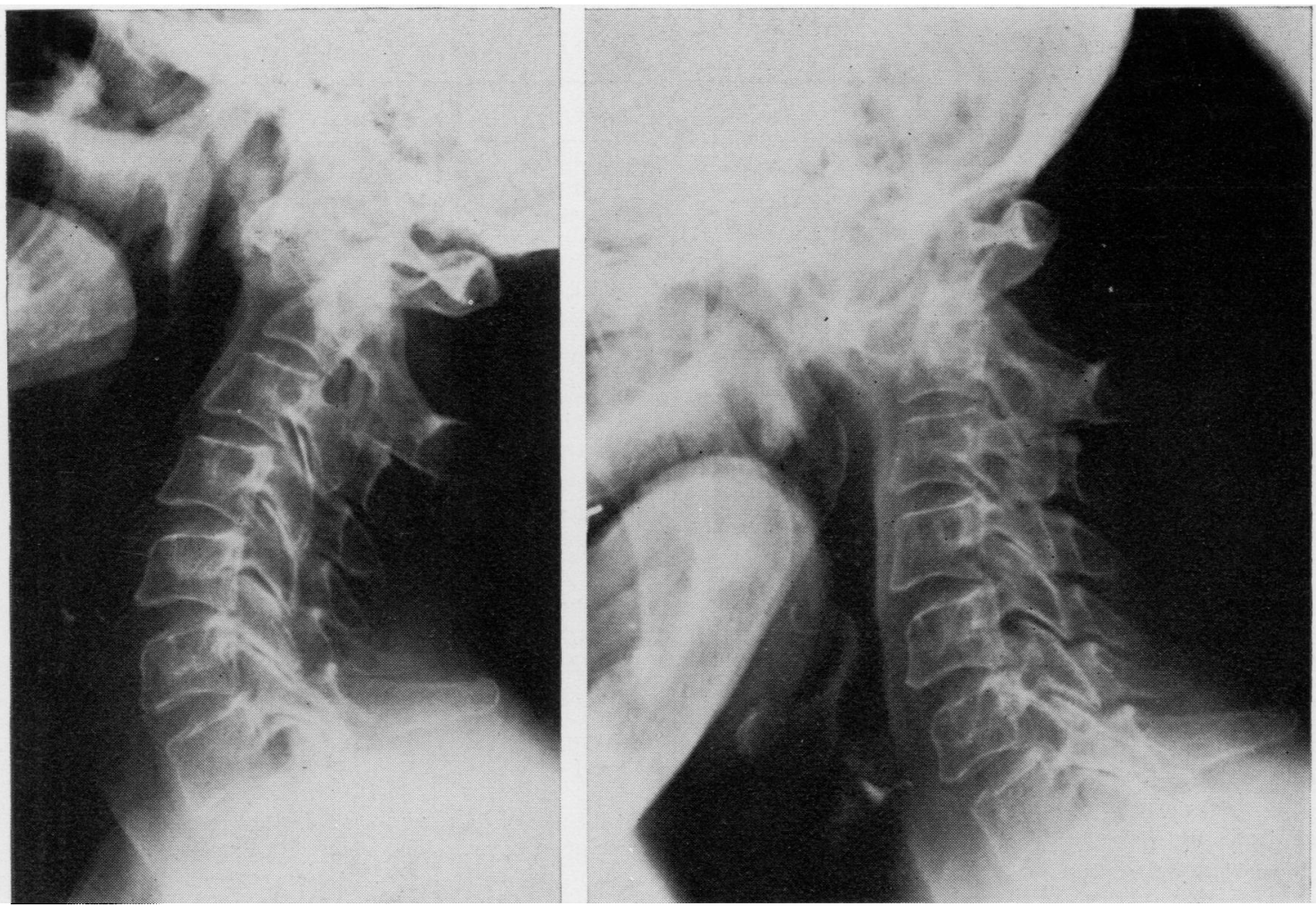

FIG. 1 A female aged 55 years with rheumatoid arthritis of 10 years' duration. After knee arthroplasty, neck symptoms became worse. Has subsequently had fusion of atlanto-axial joint.

metacarpal and metatarsophalangeal joints. At this time the neck was slightly limited in extension and lateral rotation, but radiologically normal. The patient was considered to be suffering from juvenile rheumatoid arthritis. The disease remained very active despite myocrisin for 3 years, courses of chloroquine, and maintenance corticosteroids. 11 years after the onset, because of persistent pain and soft tissue swelling in the right elbow, she was admitted for right elbow synovectomy. The preoperative cervical spine film showed, in addition to apophyseal joint fusion, an atlanto-axial subluxation of $5 \mathrm{~mm}$. (Fig 2). The anaesthetist was made aware of the problem and there were no exceptional difficulties or sequelae.

\section{Case 2}

Now aged 24, this woman had an onset of Still's disease at the age of 5 , which rapidly caused generalized arthritis. She was first referred at the age of 8 , with seronegative arthritis involving all joints, including the cervical spine. Despite intensive physiotherapy, corticosteroids, and aspirin, it was impossible to prevent recurrent flexion contractures of the hips and knees. These required bilateral femoral osteotomies for their correction in 1962. The disease is now inactive; she was able to walk with crutches and hold a light job until about a year ago, when increasing stiffness and further flexion contractures of both hips occurred. Bilateral arthroplasty was advised, but because of the loss of extension of the cervical spine (Fig. $3 a, b$ ), the initial attempt to intubate her was unsuccessful and the operation was abandoned. On a subsequent occasion, she was anaesthetized without intubation, with provision for a tracheostomy should it have been needed.

\section{Discussion}

Orthopaedic surgery is playing an increasingly prominent role in the management of patients with rheumatoid arthritis and Still's disease (Editorial, J. Bone Jt Surg., 1971). It is now considered at all stages of the disease so that cases of varying duration and activity are being assessed for possible prophylactic, restorative, or reconstructive procedures.

Atlanto-axial subluxation is one of the potential fatal complications in rheumatoid arthritis. Because of this danger it was thought useful to assess the problem in these patients coming to orthopaedic surgery in the first 6 months of 1971 .

The incidence of atlanto-axial subluxation was found to be related to the duration of disease rather than to the age of the patient. Although in Still's disease or juvenile chronic polyarthritis atlanto-axial subluxation is not frequent, when the disease has the pattern of juvenile rheumatoid arthritis (Ansell, 1969) this is not true (Case 1). 
Manipulation of the cervical spine that occurs during intubation and subsequent surgery may provide a source of danger in these patients in whom neck involvement was found to be relatively common. Previous knowledge of the state of the cervical spine should be obtained by neck radiographs in full flexion and extension. The anaesthetist must be warned of any severe atlanto-axial or lower subluxation and if necessary the patient must be sent to the operating theatre in a collar. With these precautions, in spite of a high incidence of neck abnormalities, deleterious sequelae occurred in only one patient in this series.

In those patients who had Still's disease, apophyseal joint fusion was common and produced a rigid neck; in addition, many such patients had temporomandibular joint involvement with great restriction in jaw opening so that difficulty was encountered in intubation for anaesthesia.

Apophyseal joint fusion was found to be confined to the juvenile group. Thus, if surgery is contemplated in patients with Still's disease or juvenile rheumatoid arthritis, cervical movement should be carefully examined by radiography and mouth opening should

FIG. 2 Case 1. 23-year-old girl with juvenile rheumatoid arthritis, 11 years' duration. Note atlanto-axial subluxation in full flexion

FIG. 3a, $b$ Case 2. Apophyseal joint fusion in long-standing Still's disease. Note the very small range of movement in flexion and extension

be checked. Also, with these patients, the anaesthetist must be forewarned of the possible difficulty in intubation (Brechner, 1968).

\section{Summary}

The results are given of routine radiological review of the cervical spine in 100 consecutive patients with chronic polyarthritis who had orthopaedic surgery.
Atlanto-axial subluxation was found in 14 cases and lower cervical subluxation in 11. Apophyseal joint fusion leading to severe loss of extension were common in those with a juvenile onset; particularly when this was associated with some jaw restriction due to temporo-mandibular involvement, it has led to difficulty in intubation for anaesthesia.

Previous knowledge of the abnormality and discussion with the anaesthetist will help to prevent serious sequelae.

\section{References}

Ansell, B. M. (1969) Proc. roy. Soc. Med., 62, 912 (Still's disease followed into adult life)

-, AND BYWATERS, E. G. L. (1959) Bull.rheum. Dis., 9, 189 (Prognosis in Still's disease)

Brechner, V. L. (1968) Anesth. Analg. Curr. Res., 47, 362 (Unusual problems in the management of airways)

Davis, F. W., AND MARKLEY, H. E. (1951) Ann. intern. Med. 35, 451 (Rheumatoid arthirtis with death from medullary compression)

Editorial (MCEwen, C.) (1971) J. Bone Jt Surg., 53A, 621 (Synovectomy and the rehabilitation of the patient with rheumatoid arthritis)

HopkINS, J. S. (1967) Ibid., 49B, 46 (Lower cervical rheumatoid subluxation with tetraplegia)

ISDALE, I. C., Ridings, K. W., AND TAPSELL, P. W. (1964) N.Z. med.J., 63, 140 (Rheumatic disease surgery)

Martel, W., AND ABell, M. R. (1963) Arthr. and Rheum., 6, 224 (Fatal atlanto-axial luxation in Rheumatoid arthritis)

Sharp, J., AND Purser, D. W. (1961) Ann. rheum. Dis., 20, 47 (Spontaneous atlanto-axial dislocation in alkylosing spondylitis and rheumatoid arthritis)

Whaley, K., AND Dick, W. Carson (1968) Brit. med.J., 2, 31 (Fatal subaxial dislocation of cervical spine in rheumatoid arthritis) 